Sains Malaysiana 49(9)(2020): 2211-2219

http://dx.doi.org/10.17576/jsm-2020-4909-18

\title{
Crushing Behaviour of Plain Weave Composite Hexagonal Cellular Structure
}

(Sifat Penghancuran Struktur Sel Heksagon Komposit Tenun Biasa)

\author{
M.F.M. AlkbiR*, Fatihhi Januddi, Adnan Baki, S.M. SApuan, M.S.E. Kosnan, S.B. Mohamed, M.S. \\ HAMUODA \& A. ENDUT
}

\begin{abstract}
The tradition of fibre composite materials in energy absorbing tube applications has gained interest in structural collisions in the composite materials industry. Thus, the subject of this work is the experimental investigation to understand the effects of the failure initiator at the specimen's edge, causing the increase in the specific absorbed energy (SEA), as well as the influence of the cellular structure composed of cells with small hexagonal angle exhibited high energy absorption capability. An extensive experimental investigation of an in plane crashing behavior of the composite hexagonal cellular structure between platen has been carried out. The cellular structure composed of hexagonal cells with angles varying between 45 and $60^{\circ}$. The materials used to accomplish the study are the plain weave E-glass fabric as a reinforcement and the epoxy resin system as a matrix. Furthermore, the specific energy absorption increases as the hexagonal angle increases.
\end{abstract}

Keywords: Composite; crushing behavior; hexagonal cellular structure; plain weave

\section{ABSTRAK}

Penggunaan bahan komposit fiber secara tradisi dalam tiub penyerapan tenaga telah mendapat perhatian dalam pelanggaran struktur dalam industri bahan komposit. Oleh itu, subjek kajian ini adalah untuk mengkaji kesan kegagalan pemula pada tepi spesimen, menyebabkan peningkatan pada penyerapan tenaga tertentu (SEA) dan juga pengaruh daripada struktur sel yang terdiri daripada sel dengan sudut heksagon kecil menunjukkan keupayaan penyerapan tenaga yang tinggi. Kajian menyeluruh berkenaan sifat penghancuran satah daripada struktur komposit sel heksagon telah dijalankan. Struktur sel terdiri daripada sel heksagon dengan sudut berubah antara 45 dan $60^{\circ}$. Bahan yang digunakan untuk melengkapkan kajian ini adalah fabrik E-kaca tenun biasa sebagai bahan diperkuat dan sistem resin epoksi sebagai matriks. Selain itu, penyerapan tenaga tertentu meningkat apabila sudut heksagon meningkat.

Kata kunci: Komposit; sifat penghancuran; struktur sel heksagon; tenun biasa

\section{INTRODUCTION}

In demand to ensure that both drivers and passenger's safety in case of high or medium - speed crashes, special impact structures are designed to absorb the car's kinetic energy and limit the deceleration acting on the human body. In recent automotive development in the last decades, a few methods have been suggested to improve energy absorption capability of car body components due to a greater capacity to absorb energy of composites compared to metals (Bergmann et al. 2015; Ma et al. 2015; Xu et al. 2016). The energy-absorbing capability of composite tubes essentially depends on the composite structure and configuration (Luo et al. 2016; Tarlochan et al. 2012), hybrid material and fiber orientation (Esnaola et al. 2015; Kalhor \& Case 2015; Othamn et al. 2014), trigger mechanism and natural fibre (Alkbir et al. 2016a, 2016b; Eshkoor et al. 2013; Siromani et al. 2014). Using filler substances such as metal and polymeric foams (Yan et al. 2014b), filler foam in fiber tubes (Wang et al. 2016) and externally reinforcing by composite materials (Misri et al 2015).

Othman et al. (2014) concluded that the foam-filled profile is superior to the non-filled foam composite square tube profile in terms of the capacity to absorb specific energy. Oshkovr et al. (2012) reported that triggered composites profile lead to different energy absorbing capabilities. 
Abdewi et al. (2006) studied the effect of corrugation geometry on the crushing behavior, energy absorption and failure mode of woven roving glass fibre/epoxy laminated composite tubes. Eshkoor et al. (2013) found that using the four-piece trigger configuration improved the crush force efficiency further more, a progressive failure mode was observed for these specimens. It is a good indicator to avoid catastrophic failure behavior. In another study, Yan et al. (2014a) investigated experimentally the effect of foam-filler and triggering on natural fibre reinforced composites. They studied experimentally to investigate the effects of triggering and polyurethanefoam filler and their combined effect on axial crushing crashworthiness characteristics of flax fabric reinforced epoxy composite tubes. Furthermore, we concludes that the crashworthiness parameters such as force efficiency and mean crushing load recorded the highest value with both structures (tube with foam filler and triggering tubes). On the other hand, they observed that the tubes with triggered and foam filled had the largest value than tubes with triggering only.

Elgalai et al. (2004) carried out the crushing response of composite corrugated tubes under quasi-static axial loading, which essentially intended for automobiles crashworthy application. Two types of composite tubes were tested. They concluded that the corrugation significantly enhanced the energy absorption capability of, these composite tubes. Moreover, this conclusion has to be verified for other architectures such as fabric composite tubes. Composite corrugated tubes and composite corrugated tubes.

The current work adds more observations to the prior contributions to the knowledge of the crashworthiness. This paper focus was to investigate the energy absorption capability of ring chain system with hexagonal shape, the failure mechanism, and failure mode of fabric plain weave fibre/epoxy laminated composite tube. Hexagonal composite tube have been fabricated and tested under lateral compression conditions in order to keep up comparison between different hexagonal sequences.

\section{MATERIAL AND DESIGN REQUIREMENTS}

In this section, the methods that were implemented to accomplish the study are described. The methods have been divided into two main parts. The experimental work, which deals with the fabrication and testing of ring chain with hexagonal composite tubes. All tested specimens were subjected to two types of loading conditions; quasistatic axial and lateral compressive crushing load. The structure being investigated a ring chain with hexagonal shape. The thickness of tubes is $1.5-3 \mathrm{~mm}$. Four rings were adjacent to each other vertically as shown in Figure 1. The thickness, and mass of both structures were measured and averaged.
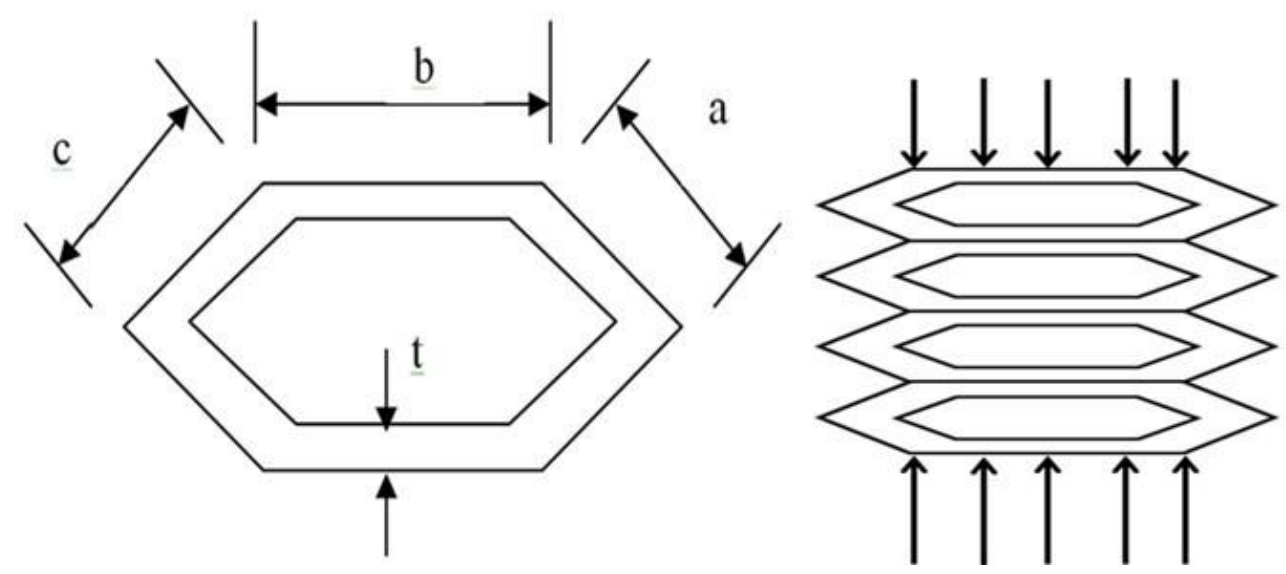

FIGURE 1. (a) Ring chain system of hexagonal, and

(b) cross sectional area

\section{MATERIAL AND FIBRE PREPARATION}

The fabric plain weave originally comes in a mat form as shown in Figure 2. Fabric plain (mat) was chopped into small pieces manually according to the dimension of the mandrel shape. The matrix used is a combination of LECO 811-563-103 Liquid Epoxy Resin and LECO 811-563104 as Hardener/Curing. The epoxy matrix was supplied by Dow Chemical Pacific, Singapore. The types of these materials are shown in Table 1. 
TABLE 1. Type of fiber material and matrix

\begin{tabular}{|c|c|}
\hline Item & Type \\
\hline Epoxy resin & LECO 811-563-103 \\
\hline Hardener & LECO 811-563-104 \\
\hline Type of fiber & Fabric plain weave \\
\hline
\end{tabular}
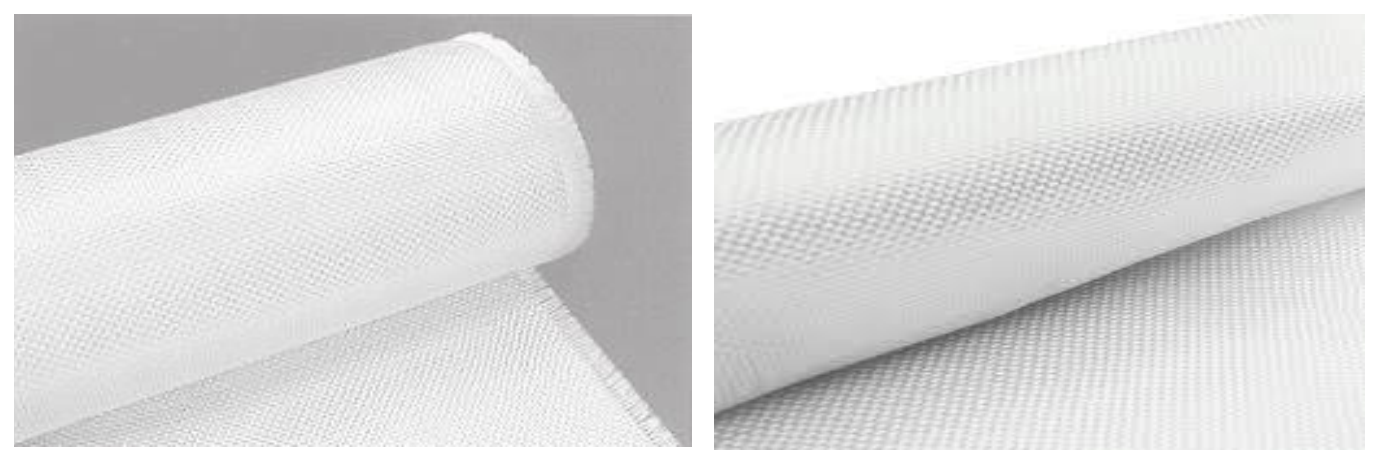

FIGURE 2. Fabric plain weave

\section{FABRICATION PROCESS}

The wet winding method was used to produce the fabric plain weave hexagonal composite tubes. The fabric plain weave is passed through a resin tank, causing resin impregnation as shown in Figure 3. Based on supplier instruction and recommendation, the mixture was mixed with ratio of $2: 1$. Then, stirred up till get humongous mixture to use.

Consistently, the fibre wrapped around the wooden mandrel. After that the roller brush was used to distribute the mixture over all mixture. To ensure all structure thickness are the same, a random measure was used between time.

The weight of the fiber mat was measured and recorded before warping and then divided by the weight of the final composite to calculate the fiber loading of $28 \%$. To ensure the mixture impregnated to the fibre layers, special monitoring was taken. To get free trapped bubble humongous structure the composite was compressed for few hours. The final structure contain two layers with thickness around 1.5 to $3 \mathrm{~mm}$. The plan weave fibre/epoxy was left at temperature $32{ }^{\circ} \mathrm{C}$ for $24 \mathrm{~h}$.
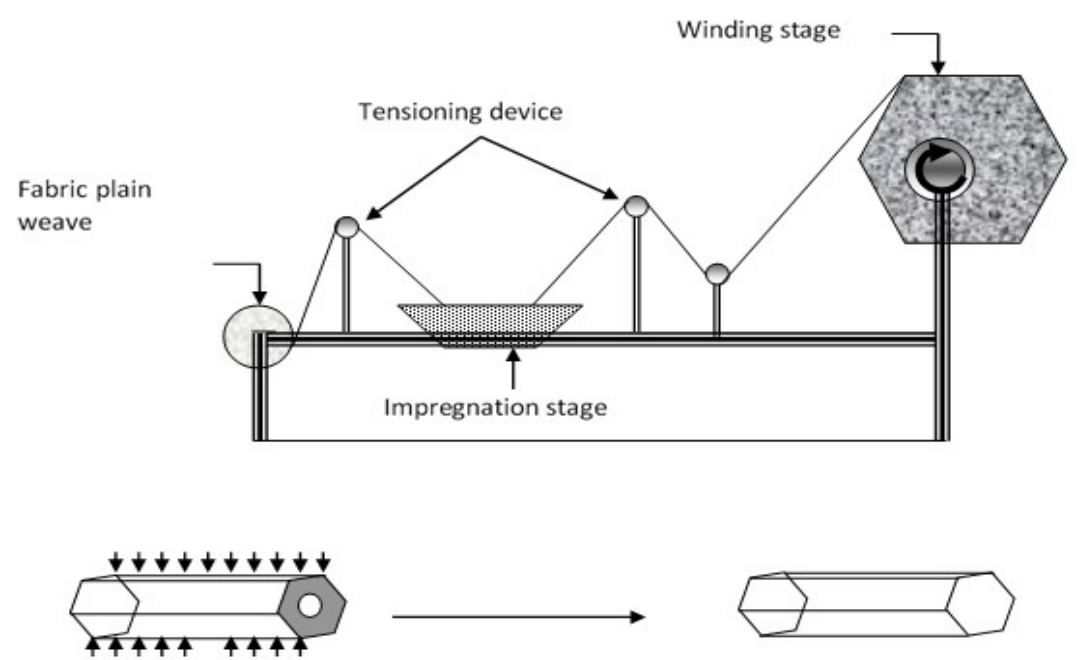

FIGURE 3. Schematic diagram of fabric plain weave fabrication process 


\section{THE TEST PROCEDURE}

Lateral compression test was carried out on each type of specimens. A static axial compression load was applied using an Instron 3382 universal testing system with a full load range of $100 \mathrm{kN}$, The load platens were set parallel to each other prior to the initiation of the test. Three tests were conducted for each specimen, which contained two layers of fibre. The tests were carried out at a speed of $15 \mathrm{~mm} / \mathrm{min}$. The load and displacement were recorded by an automatic data acquisition system. The best results of the three tests are presented; however, the results were remarkably repeatable.

\section{Crashworthiness Parameters in Composite Materials} In passenger vehicles, the ability to absorb the impact energy and survive an accident is called the 'crashworthiness' of the structure. Crashworthiness is concerned with the absorption of energy through controlled failure mechanisms and modes that enable the maintenance of a gradual decay in the load profile during absorption (Bergmann et al. 2015).

The crashworthiness parameter can be evaluated by being aware of the following:

\section{Initial peak Load : $(P)$}

The initial crushing load can be obtained directly from the load-displacement response.

\section{Mean-Crushing Load: $\left(P_{m}\right)$}

The average crushing load can be obtained by averaging the crushing load values over the crush displacement through the post-rush region.

\section{Specific Energy Absorption: (E)}

Specific energy absorption, ES, is defined as the energy absorbed per unit mass of material. The total work done or energy absorbed, $\mathrm{W}$, in crushing of composite specimens is to the area under the load-displacement curve is (1):

$$
W=\int_{0}^{S b} P d S
$$

where $W$ is the total energy absorbed in crushing of the composite tube specimen. A more characteristic property of progressive crushing mode is shown in (2):

$$
W=\int_{S i}^{S b} P d S=\bar{P}(S b-S i)
$$

where $S b$ and $S i$ are the crush distances and $\bar{P}$ is the mean crush load. The specific energy absorption capability, ES of a composite material defined as the energy absorbed per unit mass of material is given in (3):

$$
E S=\frac{W}{m}
$$

where $m$ is the mass of the composite tube. By substituting (3) into (2) we will get (4):

$$
E S=\frac{W}{m}=\frac{\bar{P}(\mathrm{Sb}-\mathrm{Si})}{V \rho}=\frac{\bar{P}(\mathrm{Sb}-\mathrm{Si})}{A L \rho}
$$

where $A$ and $L$ are the cross sectional area and length of the crushed portion of the composite tube specimen, respectively. If $\mathrm{Si}$ is much less than $\mathrm{Sb}$ then $(\mathrm{Sb}-\mathrm{Si}) \approx$ $\mathrm{Sb}$ and therefore equation (5).

$$
E S=\frac{\bar{P} \mathrm{Sb}}{A L \rho}
$$

The ratio $(\mathrm{Sb} / \mathrm{L})=\mathrm{K}$ is a measure of the collapse stability of the composite tube. For a composite tube of sufficient length, $\mathrm{K}=1$ and hence the specific energy is given by (6):

$$
E S=\frac{\bar{P}}{A \rho}=\frac{\bar{\sigma}}{\rho}
$$

where $\bar{\sigma}$ is the mean crush stress.

\section{CRUSHING HISTORY AND FAILURE MODES RING CHAIN SYSTEM OF HEXAGONAL SHAPE WITH B $=45^{\circ}$}

The load-displacement curve with deformation history for R.C.S.H. $45^{\circ}$ is shown in Figure 4. At the pre-crush stage, the load increases to its first peak $\mathrm{Pi}=0.5 \mathrm{kN}$ at 28.24 $\mathrm{mm}(0.18 \mathrm{~h})$ displacement. At that instant, matrix cracking was observed starting at the top of the first ring. The load falls suddenly to $0.3 \mathrm{kN}$ at $30.7 \mathrm{~mm}(0.2 \mathrm{~h})$ displacement, the highest load was recorded when the third ring with a value of $\mathrm{Ph}=0.7 \mathrm{kN}$ at $124.73 \mathrm{~mm}(0.83 \mathrm{~h})$ displacement. It is noted that all the rings have similar behavior in which they were crushed by local buckling failure mode.

\section{RING CHAIN SYSTEM OF HEXAGONAL SHAPE WITH B $=50^{\circ}$}

It is observed from Figure 5 that the load increases linearly to compression is about $36.74 \mathrm{~mm}(0.24 \mathrm{~h})$ displacement. A local buckling at the top of first ring in chain occurs causing the load to decrease suddenly to its lowest value of $\mathrm{PL}=0.26 \mathrm{kN}$ at $41.49 \mathrm{~mm}(0.27 \mathrm{~h})$ displacement. The load starts to rise again to a maximum value of $\mathrm{PH}=0.52 \mathrm{kN}$ at $71 \mathrm{~mm}(0.74 \mathrm{~h})$ displacement. The sudden drop appeared 


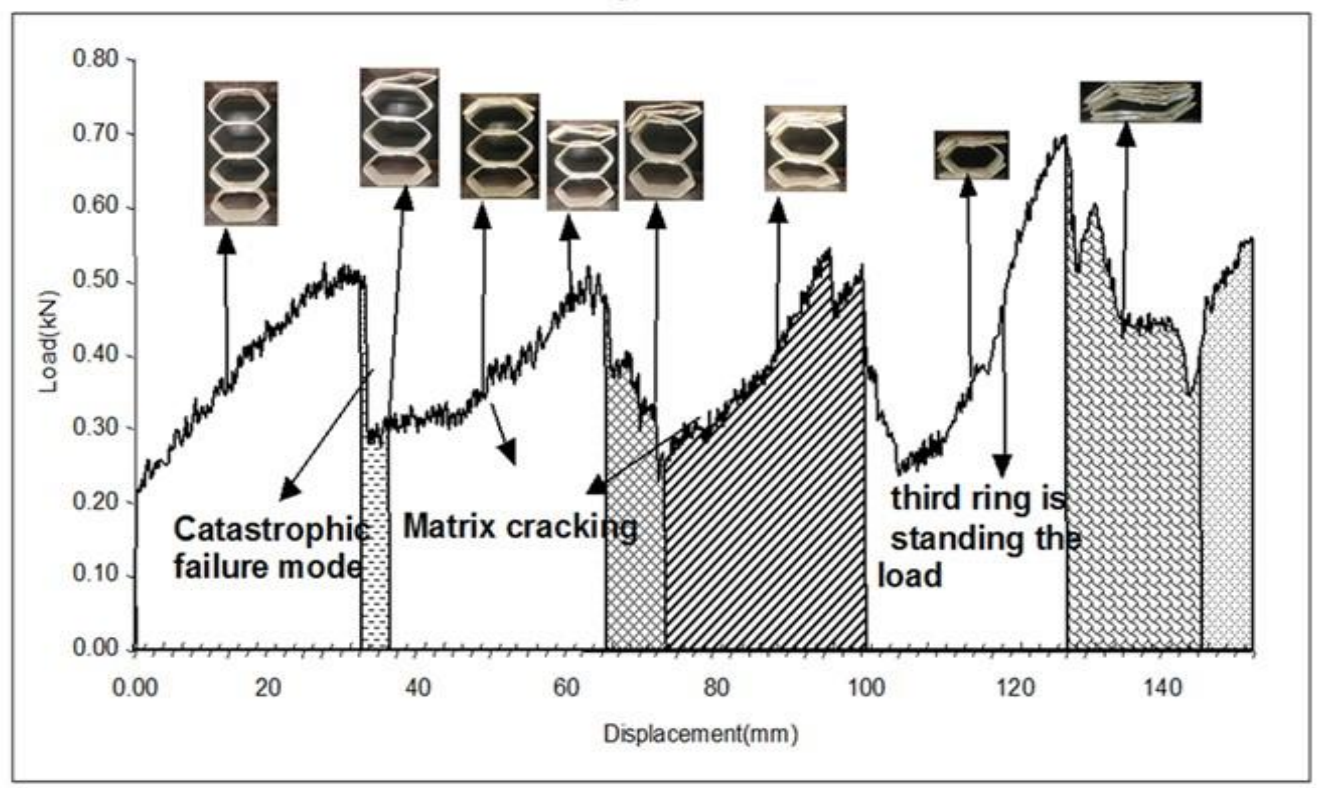

FIGURE 4. Load- displacement curve of ring chain system of hexagonal composite shape with $\beta=45^{\circ}$

again when the third ring of the chain system crushed catastrophically. After that, the load goes through an instability path in the second and the fourth ring against the load carrying capacity until they crashed.
At this stage, a progressive folding was observed. Finally, the load rises rapidly as the ring chain system becomes fully crushed.

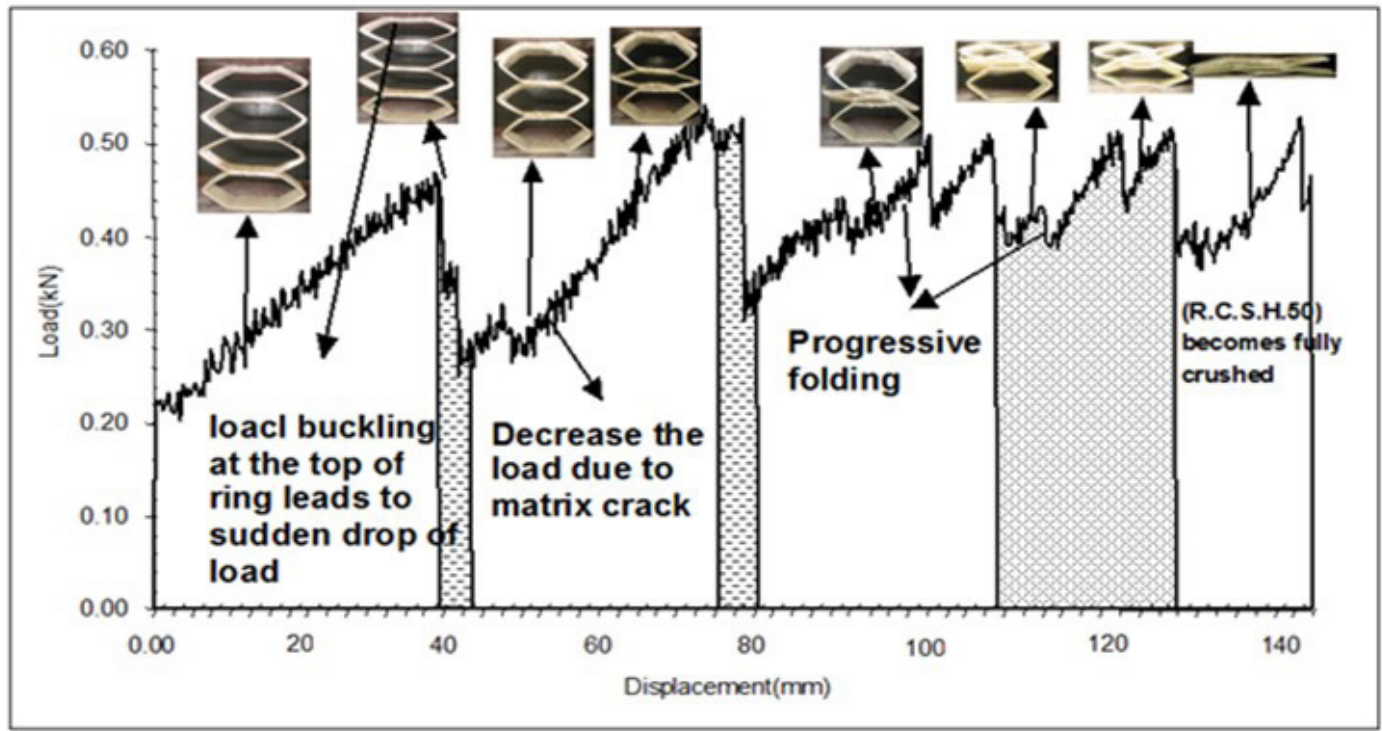

FIGURE 5. Load- displacement curve of ring chain system of hexagonal composite shape with $\beta=50^{\circ}$ 
RING CHAIN SYSTEM OF HEXAGONAL SHAPE WITH B= $55^{\circ}$

The load-displacement curve and deformation history are shown in Figure 6. Initially, the load increases nonlinearly, which terminates in peak load of $0.65 \mathrm{kN}$ at 100.5 $\mathrm{mm}(0.67 \mathrm{~h})$ displacement. This then followed a sudden drop to $0.43 \mathrm{kN}$ at $106.49 \mathrm{~mm}(0.71 \mathrm{~h})$ displacement. In this instant, the third and fourth rings are fully crushed.
After this stage, a stable load-displacement behavior is achieved. A rapid increasing of load is also evident and reaches a maximum value of $\mathrm{PH}=0.81 \mathrm{kN}$ at 133.75 $\mathrm{mm}(0.89 \mathrm{~h})$ displacement, because the first and second ring is resists the load carrying capacity. Local buckling occurred at the top of the second ring causing it to crush progressively. Finally, the load rises slightly as the ring chain system becomes fully crushed.

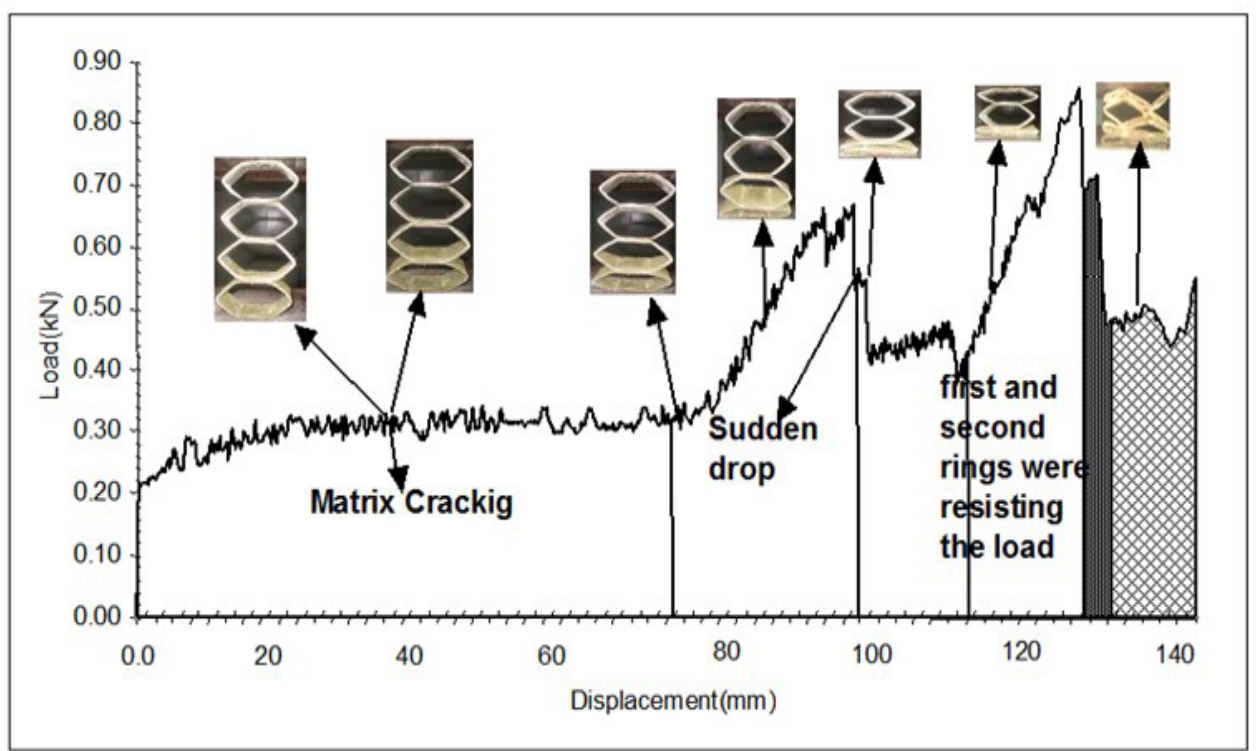

FIGURE 6. Load- displacement curve of ring chain system of hexagonal composite shape with $\beta=55^{\circ}$

RING CHAIN SYSTEM OF HEXAGONAL SHAPE WITH B $=60^{\circ}$

The load-displacement curve in Figure 7 shows the crushing history of R.C.S.H. $60^{\circ}$. Initially, the load rises to its first peak $\mathrm{Pi}=0.43 \mathrm{kN}$ at $36.7 \mathrm{~mm}(0.24 \mathrm{~h})$ displacement. The gradual drop was then noted due to local buckling at the bottom end of the fourth ring with chain. The load then increases linearly to reach the second peak, followed by a sudden drop of load to $0.41 \mathrm{kN}$ at $73.99 \mathrm{~mm}$

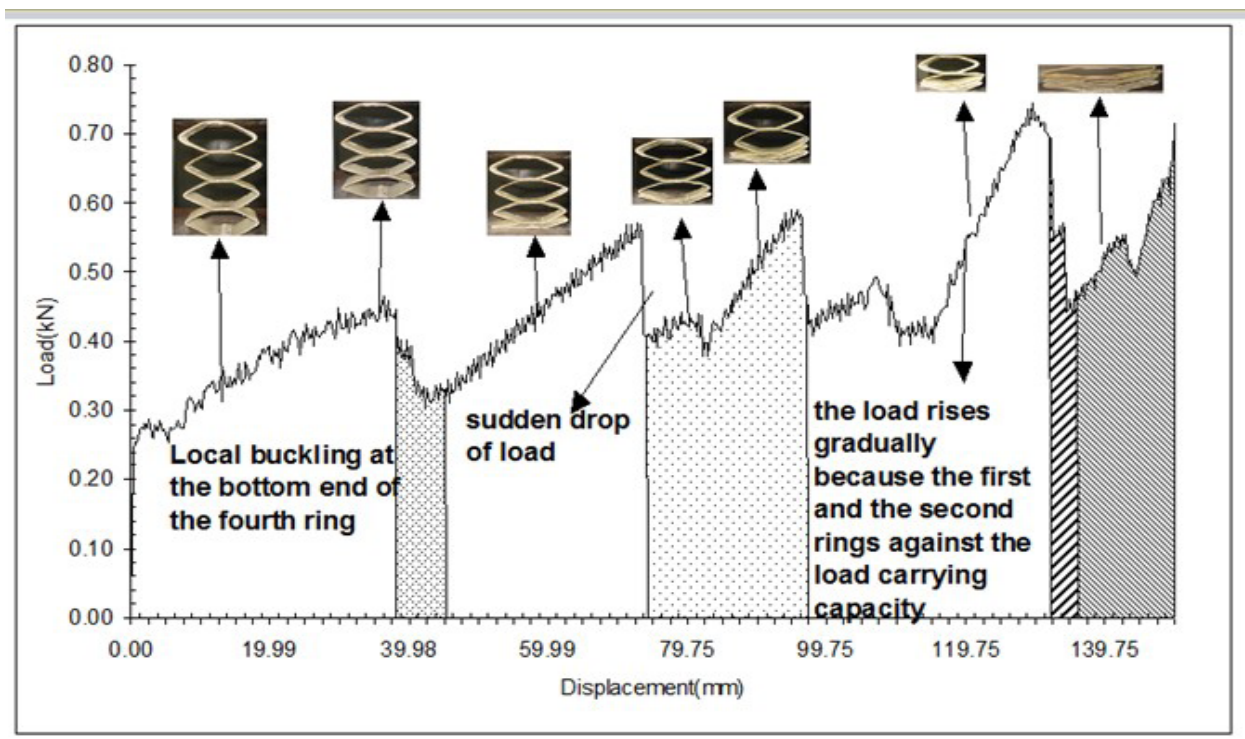

FIGURE 7. Load- displacement curve of ring chain system of hexagonal composite shape with $\beta=60^{\circ}$ 
(0.49 h) displacement. This behavior was repeated with each ring of the chain. It can be concluded that the ring chain system is crushed by matrix cracking and the local buckling failure mode.

\section{EFFECT OF HEXAGONAL ANGLE ON LOAD CARRYING} CAPACITY

The energy absorber device must be designed to alleviate the impact during the accident into a predetermined stable energy absorption mechanism. The preferable energy absorption mechanism is a progressive failure mechanism. For very thin walled structures such as cellular structure composed of hexagonal cells, the possibility of global buckling exists, because it leads to catastrophic failure mechanism. Therefore, the design must eliminate any possibility of global Euler buckling by maximizing the bending stiffness, which is the product of the axial modulus (Ex) and the moment of inertia (I), because it directly increases the critical load. The cellular dimensions are selected due to the vehicle space limits. As shown in
Figure 8 , the ring chain system of hexagonal shape with $\beta$ ranging in 45 to $60^{\circ}$ in $5^{\circ}$ steps. It can be seen from the specific energy absorption capability can be obtained at any displacement. It is noted that the high specific energy absorbed by R.C.S.H. $45^{\circ}$ with specific load value of $0.58 \mathrm{~kJ} / \mathrm{kg}$. Flowed by R.C.S.H. $55^{\circ}$ with value of $57 \mathrm{~kJ} / \mathrm{kg}$, this situation was repeated with (R.C.S.H. $55^{\circ}$ ) and (R.C.S.H. $60^{\circ}$ ) with specific load of $0.54 \mathrm{~kJ} / \mathrm{kg}$. The lowest specific energy was absorbed by (R.C.S.H. $40^{\circ}$ ) with the value of $0.46 \mathrm{~kJ} / \mathrm{kg}$.

Figure 9 shows the average for rain chain system of hexagonal composite tubes with various angles ( $\beta=45,50,55$ and $\left.60^{\circ}\right)$ under lateral load. The highest average load of $\mathrm{Pm}=0.6 \mathrm{kN}$ is realized by R.C.S.H. $45^{\circ}$ followed by R.C.S.H. $50^{\circ}$, and R.C.S.H. $60^{\circ}$ with an average loads $\mathrm{Pm}=0.48 \mathrm{kN}, 0.47 \mathrm{kN}, 0.40 \mathrm{kN}$, respectively. The R.C.S.H. $55^{\circ}$ shows the lowest average crushing load of $0.34 \mathrm{kN}$, this may be due to imperfection of fabrication process or some voids occurred in the specimen.

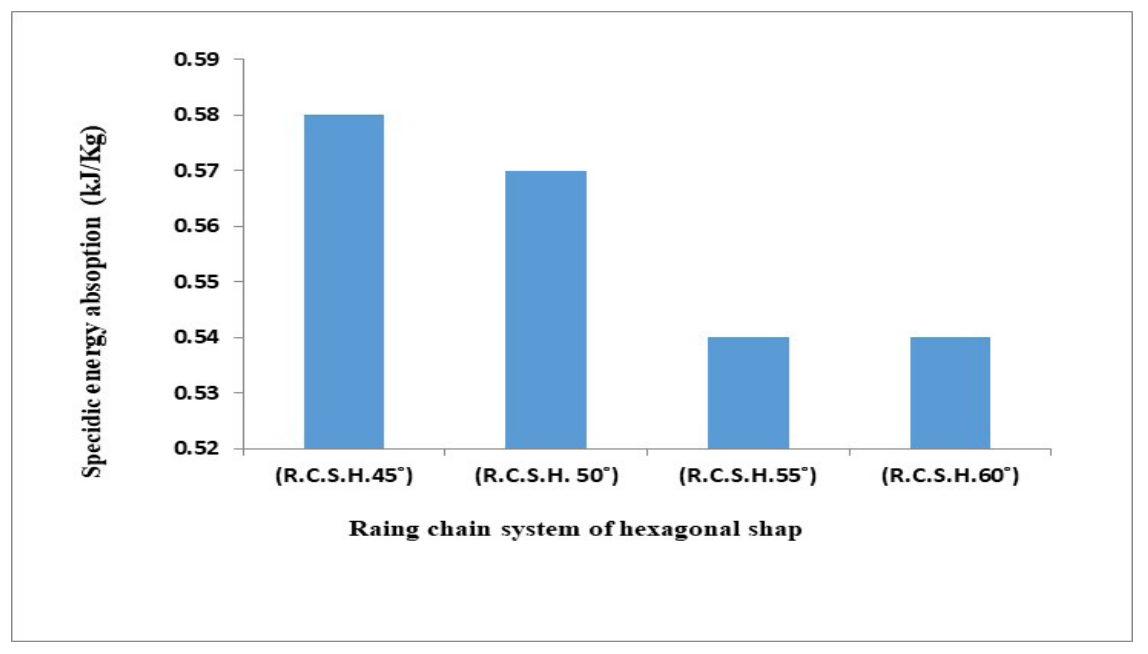

FIGURE 8. Specific energy absorption for ring chain system of hexagonal shape with $\beta=35,40,45,50,55$ and $60^{\circ}$

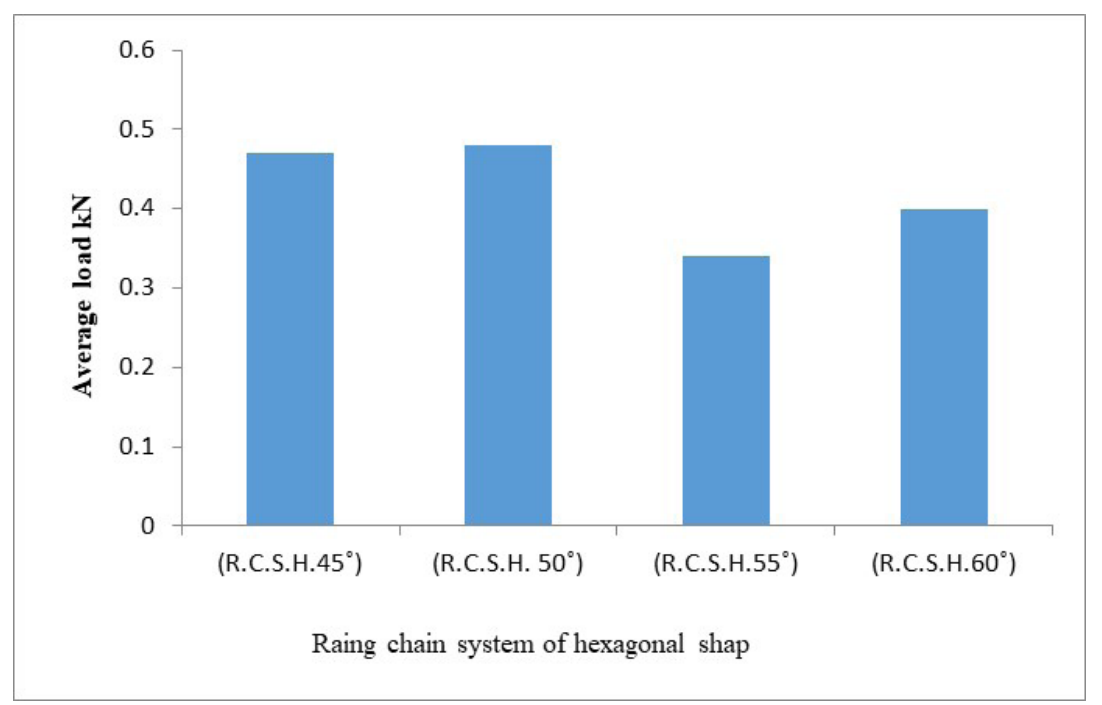

FIGURE 9. Average load for ring chain system of hexagonal shape with $\beta=45,50,55$ and $60^{\circ}$ 


\section{CONCLUSION}

The geometry of hexagonal cell has a significant effect on the energy absorption capability of the cellular structures. As the angle of hexagonal cell increases, ends cell transfer the load to the middle cells. The bending stresses increase as the hexagonal angle increases. Next, cellular structure composed of cells with small hexagonal angle exhibited high energy absorption capability. Despite the change of crushing history sequence, progressive failure mode is observed for all tested specimens.

\section{ACKNOWLEDGEMENTS}

We would like to express our deepest appreciation to Universiti Kuala Lumpur for the financial support to complete this report. Furthermore, we would like to thank Universiti Putra Malaysia for the facilities provided to carry out this research project. The authors declare that they have no conflict of interest.

\section{REFERENCES}

Abdewi, E.F., Sulaiman, S., Hamouda, A.M.S. \& Mahdi, E. 2006. Effect of geometry on the crushing behaviour of laminated corrugated composite tubes. Journal of Materials Processing Technology 172(3): 394-399.

Alkbir, M.F.A. \& Ishak, M.R. 2016a. Lateral crushing properties of non-woven kenaf (mat)-reinforced epoxy composite hexagonal tubes. International Journal of Precision Engineering and Manufacturing 17(7): 965-972.

Alkbir, M.F.M., Sapuan, S.M., Nuraini, A.A. \& Ishak, M.R. 2016b. The effect of fiber content on the crashworthiness parameters of natural kenaf fiber-reinforced hexagonal composite tubes. Journal of Engineered Fibers and Fabrics 11(1): 75-86.

Bergmann, T., Heimbs, S. \& Maier, M. 2015. Mechanical properties and energy absorption capability of woven fabric composites under \pm 45 off-axis tension. Composite Structures 125: 362-373.

Eshkoor, R.A., Oshkovr, S.A., Sulong, A.B., Zulkifli, R., Ariffin, A.K. \& Azhari, C.H. 2013. Effect of trigger configuration on the crashworthiness characteristics of natural silk epoxy composite tubes. Composite Part B: Engineering 55(1): 5-10.

Esnaola, A., Ulacia, I., Aretxabaleta, L., Aurrekoetxea, J. \& Gallego, I. 2015. Quasi-static crush energy absorption capability of E-glass/polyester and hybrid E-glass-basalt/ polyester composite structures. Materials \& Design 76 : 18-25.

Elgalai, A.M., Mahdi, E., Hamouda, A.M.S. \& Sahari, B.S. 2004. Crushing response of composite corrugated tubes to quasistatic axial loading. Composite Structures 66(1-4): 665-671.

Kalhor, R. \& Case, S.W. 2015. The effect of FRP thickness on energy absorption of metal-FRP square tubes subjected to axial compressive loading. Composite Structures 130: 44-50.

Luo, H., Yan, Y., Meng, X. \& Jin, C. 2016. Progressive failure analysis and energy-absorbing experiment of composite tubes under axial dynamic impact. Composite Part B: Engineering 87: 1-11.

Ma, Y., Sugahara, T., Yang, Y. \& Hamada, H. 2015. A study on the energy absorption properties of carbon/aramid fiber filament winding composite tube. Composite Structures 123: 301-311.

Misri, S., Sapuan, S.M., Leman, Z. \& Ishak, M.R. 2015. Torsional behaviour of filament wound kenaf yarn fibre reinforced unsaturated polyester composite hollow shafts. Materials \& Design 65: 953-960.

Oshkovr, S.A., Eshkoor, R.A., Taher, S.T., Ariffin, A.K. \& Azhari, C.H. 2012. Crashworthiness characteristics investigation of silk/epoxy composite square tubes. Composite Structures 94(8): 2337-2342.

Othman, A., Abdullah, S., Ariffin, A.K. \& Mohamed, N.A.N. 2014. Investigating the quasi-static axial crushing behavior of polymeric foam-filled composite pultrusion square tubes. Materials \& Design 63: 446-459.

Siromani, D., Henderson, G., Mikita, D., Mirarchi, K., Park, R., Smolko, J., Awerbuch, J. \& Tan, T.M. 2014. An experimental study on the effect of failure trigger mechanisms on the energy absorption capability of CFRP tubes under axial compression. Composites Part A: Applied Science and Manufacturing 64: 25-35.

Tarlochan, F., Ramesh, S. \& Harpreet, S. 2012. Advanced composite sandwich structure design for energy absorption applications: Blast protection and crashworthiness. Composite Part B: Engineering 43(5): 2198-2208.

Wang, L., Liu, W., Fang, Y., Wan, L. \& Huo, R. 2016. Axial crush behavior and energy absorption capability of foamfilled GFRP tubes manufactured through vacuum assisted resin infusion process. Thin-Walled Structures 98: 263-273.

Xu, J., Ma, Y., Zhang, Q., Sugahara, T., Yang, Y. \& Hamada, H. 2016. Crashworthiness of carbon fiber hybrid composite tubes molded by filament winding. Composite Structures 139: 130-140.

Yan, L., Chouw, N. \& Jayaraman, K. 2014a. Effect of triggering and polyurethane foam-filler on axial crushing of natural flax/ epoxy composite tubes. Materials \& Design 56: 528-541.

Yan, L., Chouw, N. \& Jayaraman, K. 2014b. Lateral crushing of empty and polyurethane-foam filled natural flax fabric reinforced epoxy composite tubes. Composite Part B: Engineering 63: 15-26.

M.F.M. Alkbir*, Fatihhi Januddi, Adnan Baki \& M.S.E. Kosnan Facilities Maintenance Engineering

UniKL Malaysian Institute of Industrial Technology (MITEC) Persiaran Sinaran Ilmu, Bandar Seri Alam 81750 Masai, Johor Darul Takzim Malaysia

\section{S.M. Sapuan}

Department of Mechanical and Manufacturing Engineering Universiti Putra Malaysia 43400 UPM Serdang, Selangor Darul Ehsan Malaysia 
S.B. Mohamed \& A. Endut

Faculty of Innovative Design and Technology

Universiti Sultan Zainal Abidin (UniSZA)

21300 Kuala Terengganu, Terengganu Darul Iman

Malaysia

M.S. Hamuoda

Department of Mechanical and Industrial Engineering

College of Engineering

Qatar University

P.O. Box 2713, Doha

Qatar
*Corresponding author; email: munir@unikl.edu.my

Received: 15 October 2019

Accepted: 15 May 2020 